\title{
Caixa 150 Anos: poupança e liberdade de escravos na segunda metade do século XIX
}

\author{
'CAIXA' 150 YEARS: SAVINGS AND FREEDOM OF SLAVES IN THE SECOND \\ HALF OF THE CENTURY XIX
}

Neuza Benedita Silva ZATTAR*

Resumo: Neste trabalho, propomos analisar, na perspectiva teórica da Semântica do Acontecimento (2002, 2005), as relações de sentidos entre "poupança", "liberdade", "alforria" e "escravo" nos processos sócio-históricos de sua significação, na segunda metade do século XIX, e como esses sentidos se constituem na relação entre a propaganda "Caixa 150 Anos" e dicionários lusitanos e brasileiros em dois momentos: na segunda metade do século XIX, à época que a propaganda da Caixa nos transporta, e no início do século XXI, época em que a propaganda é criada.

Palavras-chave: Semântica do Acontecimento. Caixa Econômica. Poupança.

Abstract: In this work, we propose to examine, in theoretical perspective of Semantics of the Event $(2002,2005)$, the relations between the senses of "savings", "freedom", "alforria" and "slave" in the socio-historical processes of its meaning, during the second half of the 19th century, as long as the way these senses are constituted in the relationship between the advertisement "Caixa 150 anos" and lusitanian and brazilian dictionaries in two moments: in the second half of the 19th century, by the time that the Caixa's advertisement transports us, and the beginning of the 21 st century, by the time the advertisement was created.

Key-words: Semantics of the Event. Caixa Econômica. Savings.

* Doutora em Linguística pela Unicamp. Professora do Departamento de Letras/ Campus de Cáceres-MT. Contato: neuza.zattar@top.com.br. 


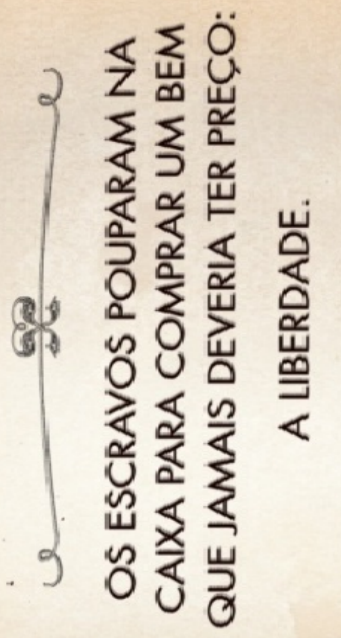

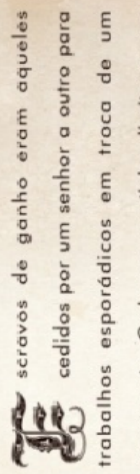

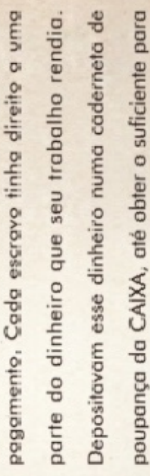

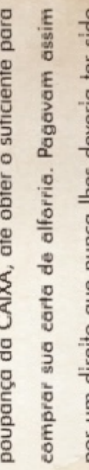
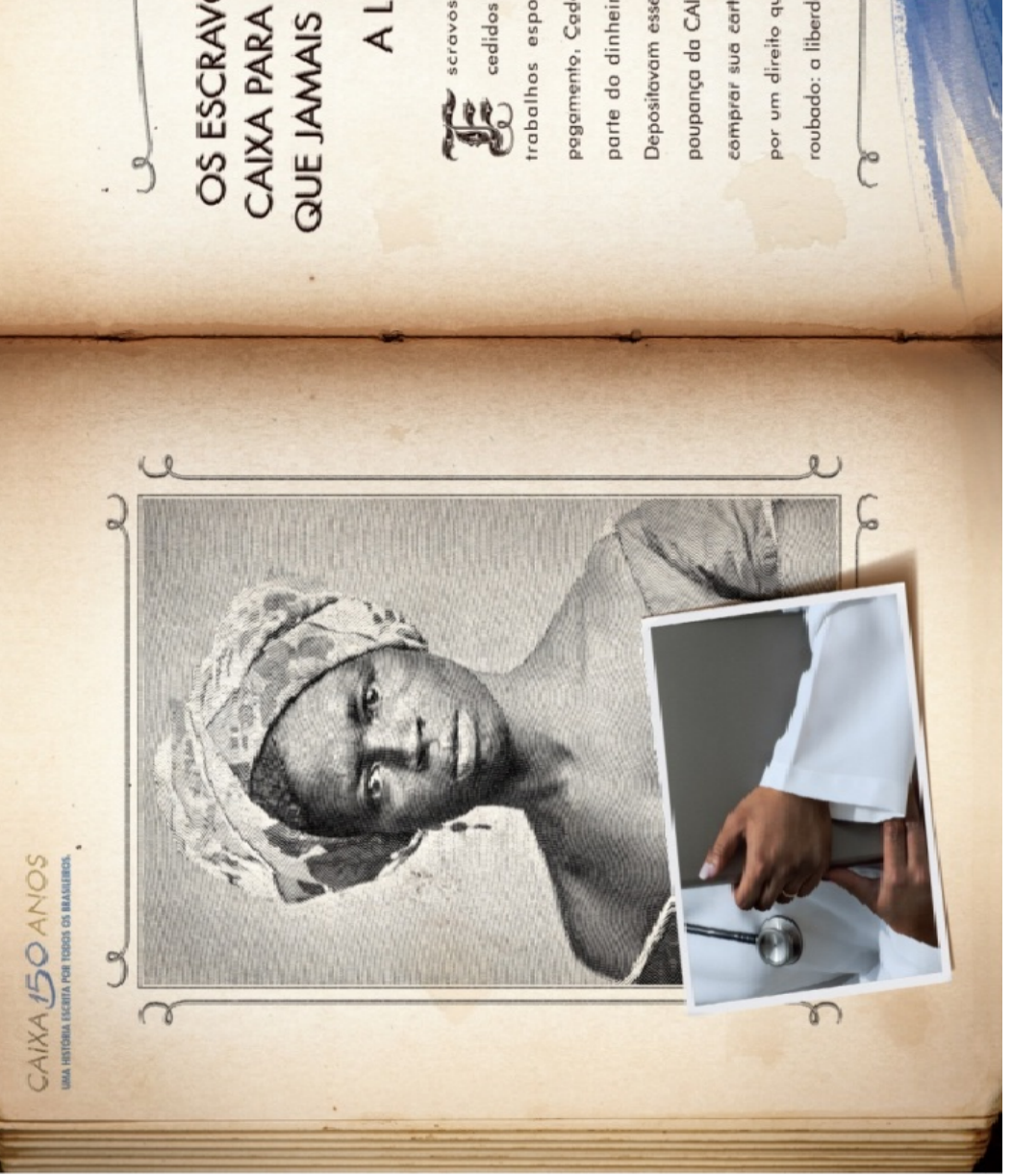

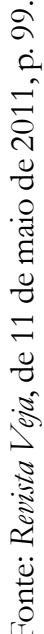




\section{Considerações Iniciais}

Na comemoração dos 150 anos da Caixa Econômica Federal, circula na mídia impressa e eletrônica a quinta de uma série de propagandas, que rememora a escravidão no Brasil, compondo, ao mesmo tempo, um ponto de encontro entre o passado - a imagem de uma escrava de ganho que poupou suas economias na Caixa -, e a atualidade - a imagem da geração dos libertos refletida no prontuário médico, significando a ascensão profissional de seus descendentes projetada pela conquista de liberdade intermediada pela Caixa.

No slogan "Caixa 150 Anos. Uma história escrita por todos os brasileiros", a propaganda coloca em foco a forma material da língua, que é histórica, com sua opacidade e seus equívocos (ORLANDI, 1996), representada pela Caixa Econômica (banco autorizado a receber depósitos de escravos), o escravo de ganho (uma das categorizações do escravo), e a alforria (a liberdade adquirida por meio de compra).

Essa confluência linguístico-histórica dá à Caixa o papel de agente intermediador da liberdade adquirida por compra, uma das formas de concessão ${ }^{1}$ de liberdade a escravos poupadores da Caixa Econômica, na segunda metade do século XIX (1861), época em que os escravos juridicamente eram considerados coisas ou objetos de direito, mas, contraditoriamente, poupavam suas economias num banco estatal, anterior à Lei do Ventre Livre, que somente em 1871 legaliza essa prática, permitindo ao escravo a formação de um pecúlio e, ao mesmo tempo, constituindo um paradoxo, ao conceder ao escravo o mesmo direito que dá ao homem livre, de ocupar um lugar social, o de locutor-poupador, na enunciação da Caixa Econômica.

Esta e outras contradições atravessam as enunciações que refletem a condição jurídica dos escravos no Brasil que, não dispondo de uma lei que regulamentasse a sua liberdade, lançavam mão do instrumento da alforria, uma lei costumeira (não escrita) que, não sendo contestada pelas autoridades brasileiras, funcionou juridicamente para atender, em grande parte, ao que prenunciava o artigo $6^{\circ}$ da Constituição Imperial: "São cidadãos brasileiros: I. Os que no Brasil tiverem nascido, quer sejam ingênuos ou libertos".

${ }^{1}$ Além da alforria onerosa (comprada pelo escravo), existiam, ainda, a alforria gratuita e a condicional. 
Neste trabalho, propomos analisar as relações de sentidos entre "poupança", "liberdade", "alforria" e "escravo" nos processos sócio-históricos de sua significação, na segunda metade do século XIX, e como esses sentidos se constituem na relação entre a propaganda da Caixa e dicionários lusitanos e brasileiros, em dois momentos: na segunda metade do século XIX, à época que a propaganda da Caixa nos transporta, e no início do século XXI, época em que a propaganda é criada.

Entendemos, como Nunes (2002), que o saber linguístico do dicionário é um produto histórico, localizado em um tempo e em um espaço, e neste estudo do saber lexicográfico sobre as palavras em duas épocas, buscaremos compreender não apenas as semelhanças e as diferenças entre as palavras mostradas pelos dicionários, mas também como esses sentidos produzidos em tempos diferentes da história das palavras constituem a temporalidade do acontecimento enunciativo da propaganda da Caixa Econômica Federal.

\section{Análise}

Compartilhando com Guimarães (2006, p. 116) que a "significação se dá pela relação do funcionamento da língua com suas questões sócio-históricas", vamos tomar o dicionário para além de um instrumento linguístico, que produz no imaginário dos leitores, um conjunto de possibilidades sinonímicas ou definitórias postas como sentidos naturalizados, ou de um artefato lexicográfico que armazena conceitos, sentidos e usos expressos numa língua. Vamos compreender o dicionário como um conjunto de textos que integram cada um dos verbetes que o compõem, afetados por um memorável que transpõe os sentidos de quem os formula, pela sua própria elaboração que, segundo Nunes (2006, p. 24-25), “consiste em um trabalho sobre o já-dito, um trabalho de seleção, reformulação, retomada, ruptura, etc.".

Nesse sentido, o dicionário, enquanto um conjunto de textos, estabelece relações de sentidos com textos já ditos em outros dicionários e em outros textos, constitui a unidade imaginária da língua de uma nação, provocando o efeito de completude da representação da língua.

Para o nosso estudo, escolhemos quatro dicionários, a saber: o Diccionario da Lingua Portugueza, de Antonio de Moraes Silva (1789); o Dicionário Contemporâneo da Lingua Portuguesa, de Franscisco Júlio de Caldas Aulete 
(on-line); o Novo Dicionário da Lingua Portuguesa, de Aurélio Buarque de Holanda Ferreira (1975); e o Dicionário Houaiss da Lingua Portuguesa (2001).

Os dois primeiros, de origem lusitana, respectivamente, inauguram o registro da história lexicográfica da nação portuguesa, e retomam/ acrescentam, um século depois, o que está dizendo a sociedade portuguesa, a partir do que ela já disse. Os dois últimos, brasileiros, mantêm a herança lexicográfica portuguesa, enriquecendo-a de brasileirismos ${ }^{2}$, oriundos de outros povos, principalmente indígenas e africanos, com os quais o Brasil conviveu/convive, legitimando o português do Brasil e, ao mesmo tempo, constituindo a identidade do país.

Para analisar como se constituem as relações de sentidos entre "poupança", "liberdade", "alforria" e "escravo" nos dicionários selecionados e no espaço enunciativo da propaganda, vamos começar com o verbete "alforria" nos dicionários lusitanos e brasileiros da atualidade, a partir da apresentação dos autores dos dicionários.

Moraes (1789) - $1^{a}$ edição

O dicionário Moraes, referência nos estudos lexicográficos no Brasil, foi publicado em Portugal por um brasileiro, em 1789, época em que o Brasil, na condição de colônia, vivia sob o domínio de Portugal e em franco comércio de escravos vindos da costa africana. No período que antecede a publicação desse dicionário, o português europeu era a língua oficial no Brasil.

Caldas Aulete (1881) - versão on-line

De origem também lusitana, o dicionário Aulete originalmente foi publicado numa época mais próxima à extinção do tráfico atlântico dos escravos (1850) e à criação da Caixa Econômica no Brasil (1861), e a poucos anos da passagem da Monarquia para a República, momento em que "se constitui a sobreposição do português como língua oficial e língua nacional” (GUIMARÃES, 2008, p. 9).

2 Cf. Horta (2001, p. 71), “os brasileirismos eram considerados 'empréstimos' ou 'influências' das línguas com as quais o português teve contato no Brasil, a saber, sobretudo, as línguas indígenas e africanas" 
Aurélio (1975) - $1^{\mathrm{a}}$ edição, $5^{\mathrm{a}}$ impressão

Um dos mais importantes dicionários do país, do final do século XX, foi publicado em contextos históricos da ditadura militar e, segundo Guimarães (1996, p. 133), "transformou-se no dicionário oficial do português do Brasil”. A origem do dicionário Aurélio não se vincula a trabalho acadêmico, pelo fato de, à época, os trabalhos da lexicografia, na academia brasileira, serem ainda incipientes.

Houaiss (2001) - $1^{\mathrm{a}}$ edição

Publicado no início do século XXI, coloca-se como um dos mais completos dicionários da Língua Portuguesa do Brasil, da atualidade, e também como obra de referência para os países lusófonos. Cabe destacar que, treze anos antes de sua publicação, a língua portuguesa é declarada o idioma oficial da República Federativa do Brasil pela Constituição Federal e, nessa nova fase republicana, aos brasileiros são 'devolvidos' os direitos civis, sociais e políticos.

\section{Alforria}

\begin{tabular}{|l|l|}
\hline Moraes (1789) & Aulete (on-line) \\
\hline Alforria, s. f. liberdade concedida & (al.for.ri.a) sf. 1. Liberdade dada \\
ao escravo. & ao escravo por seu senhor ou por \\
& autoridade (esp. mediante \\
& documento oficial). 2. Fig. \\
& Libertação, liberação de alguma \\
& obrigação; liberdade. \\
& [F.: Do ár. al-burria.] \\
\hline
\end{tabular}

\begin{tabular}{|l|l|}
\hline Aurélio (1975) & Houaiss (2001) \\
\hline Alforria. [Do ár. al-hurriâ.] $S . f .1$. & alforria $S . f$. (s.XV, cf. IVPM). 1. \\
Liberdade concedida ao escravo; & liberdade que se concede ao \\
manumissão. 2. P. ext. Libertação & escravo; manumissão. 2. $p$. ext. \\
de qualquer jugo ou domínio. & qualquer libertação, emancipação. \\
& ETIMO. ár. al-hurriiâ. 'estado de \\
& homem livre, não escravo; \\
& liberdade'. \\
\hline
\end{tabular}


Nos dois primeiros dicionários lusitanos, as definições do verbete "alforria" dizem algo e/ou atestam algo sobre as práticas de liberdade a que os escravos eram sujeitos na sociedade escravocrata. Em Moraes, a definição incide sobre um sujeito universal, e em Aulete, rememora-se uma cena enunciativa constituída de figuras que representam o escravo, o senhor, a autoridade, no caso, um tabelião, que mediava a liberdade "mediante o documento oficial", a carta de alforria, que legitimava essas relações. No espaço de enunciação em que se constitui essa cena, a língua é normativamente dividida e funciona como condição para se afirmar o pertencimento dos não incluídos e a igualdade dos desigualmente divididos (GUIMARÃES, 2002, p. 18).

Enquanto a definição de Moraes pode ser compreendida como genérica, no sentido de que "liberdade concedida" não faz referência a nenhum tipo de concessão da liberdade, a de Aulete é mais específica, por descrever o processo de liberdade pelo mecanismo de alforria onerosa, que inclui uma relação comercial-econômica e jurídica entre quem vende, quem compra, quem registra o objeto comercializado, representado pela carta de alforria.

Nas acepções formuladas pelos locutores-dicionaristas, embora remetam à liberdade do escravo, o funcionamento não é o mesmo: em Moraes, a "liberdade" aparece como julgada, sentenciada, enquanto em Aulete, a acepção se dá em "um espaço particularizado por uma deontologia específica que distribui os lugares de enunciação no acontecimento" (GUIMARÃES, 2002, p. 23).

Com relação aos sentidos postos no verbete "alforria", Moraes traz a memória de alforria do modo como é dita na sociedade, de modo geral, enquanto que Aulete, pela particularidade descritiva, nos parece ter tido acesso às cartas de alforria. Em Moraes, silencia-se o sujeito que concede a liberdade, e, em Aulete, temos uma definição na voz passiva, em que o sujeito agente (o senhor) e o sujeito paciente (o escravo) mostram uma relação de atividade e passividade comum nas práticas de linguagem da alforria.

O dicionário Aurélio retoma a definição de "alforria" em Moraes, reescriturando-a por repetição. A esse modo de redizer o mesmo, Guimarães (2002) chama de procedimentos de deriva do sentido próprios da textualidade, ou seja, esse procedimento se dá quando um nome e/ou expressão, ao ser reescriturado, os seus sentidos tornam-se outros. À medida que se reescritura o verbete de um dicionário para outro, novos locutores se 
constituem, produzindo dizeres afetados por outros dizeres e/ou reinterpretando os sentidos postos. A “manumissão", outra acepção dada à "alforria" por Aurélio, remete a um dispositivo jurídico pouco usual nas práticas de liberdade no Brasil, embora, segundo Cunha (1983 apud ZATTAR, 2000, p. 29), a referência à lei da manumissão ou da alforria onerosa fosse comum nos registros de quase todos os viajantes que passaram pelo Brasil e que trataram dessa temática.

A definição "liberdade que se concede ao escravo", dada à "alforria" por Houaiss, é uma reescritura por substituição das definições de Moraes e Aurélio. Nessa acepção, a estrutura da oração relativa "que se concede ao escravo" equivale à sinonímia estrutural "concedida ao escravo", que expressa um outro modo de dizer o mesmo. Observa-se, ainda, o apagamento do sujeito agente, o que "vende" ou "concede" a liberdade ao escravo.

Jean Dubois et al. (1973, p. 167) diz que, em um dicionário, definição

... é a análise semântica da palavra de entrada. Consta de uma série de paráfrases sinonímicas da palavra de entrada, constituindo cada paráfrase, distinta das outras, um sentido ou, na terminologia lexicográfica, uma acepção. As definições (ou sentidos), distinguidas uma das outras por números, travessões, barras, etc., sucedem-se segundo uma relação histórica ou lógica.

Considerando que cada palavra tem sua história de enunciação (GUIMARÃES, 2002), a definição da palavra-entrada em dicionário é constituída de um enunciado definidor ao qual se juntam outros enunciados que, em conjunto, buscam dar a forma material e histórica à palavra-entrada, afetados pelas relações que estabelecem com outros enunciados, em que uns enunciados se incorporam ao texto do verbete e outros não.

Com exceção de Aulete, nos demais dicionários em estudo, as acepções de "alforria" não aparecem determinadas pelas modalidades que as constituem, o que significa dizer que a rememoração se dá como parte dos enunciados já ditos, apagando outros dizeres. O emprego das formas "dada", "concedida" e "que se concede" oculta as formas de concessão da liberdade (onerosa, gratuita e condicional); as primeiras, flexionadas no particípio, produzem o efeito de liberdade consumada, já dada, enquanto a última, com o verbo no presente do indicativo, exprime o ato jurídico e econômico-social em que se enuncia a liberdade. 
Podemos dizer que os sujeitos lexicográficos (lusitanos e brasileiros) definem "alforria" afetados por uma memória das práticas escravocratas vivenciadas em Portugal que, transportadas pelos colonizadores, foram reproduzidas no Brasil, por mais de três séculos. E os dicionários de época trazem, pela forma de definição, os costumes e os modos de dizer da sociedade em determinada época, movimentando o passado e o presente do léxico da língua portuguesa de Portugal.

\section{Escravo}

\begin{tabular}{|l|l|}
\hline Moraes (1789) & Aulete (on-line) \\
\hline Escravo, adj. cativo, que está sem & (es.cra.vo) sm. 6 Aquele que está \\
liberdade, no estado de servidão. $\$$ & sob o poder de um senhor, como \\
f. Escravo dos vícios, paixões, o & sua propriedade privada. \\
escravo corpo,, Sagram. c. 8:, alma & [F.: Do lat. med. sclavus, ou do gr. \\
----, c.10. & sklábos.] \\
\hline
\end{tabular}

\begin{tabular}{|l|l|}
\hline Aurélio (1975) & Houaiss (2001) \\
\hline Escravo. [Do gr. bizantino sklábos, & escravo adj. s. m. (s. XV cf. Fich. \\
atr. do lat. med. sclavu 'eslavo'. [...] & IVPM) 1 que ou aquele que, \\
Adj. Que está sujeito a um senhor, & privado da liberdade, está \\
como propriedade dele: homens & submetido à vontade absoluta de \\
escravos. S. $m$. 4. Aquele que está & um senhor, a quem pertence \\
sujeito a um senhor, como & como proprie-dade. \\
propriedade dele: "O bom escravo & ETIM.lat.medv. slavus, sclavus (s.X), \\
é o pior senhor" prov.. & $\begin{array}{l}\text { do grego biz. sklábo, sklabenós, } \\
\text { 'eslavo', mais tarde 'escravo, } \\
\text { cativo', e este de sloveninu, nome } \\
\text { que se dava à fam. de povos } \\
\text { eslavos; a mudança semântica se } \\
\text { explica pelo fato de os germanos e } \\
\text { os bizantinos escravizarem um } \\
\text { grande número de indivíduos } \\
\text { eslavos na Europa central, durante } \\
\text { a Idade Média; [...]. }\end{array}$ \\
\hline
\end{tabular}


Em Moraes, a categoria do verbete "escravo", como adjetivo, traz acepções que mostram a imagem do estado de escravidão a que é submetido o escravo, ao predicá-lo por "cativo, que está sem liberdade, no estado de servidão". Aqui, as acepções não recaem sobre a definição do escravo e nem sobre os espaços rurais e urbanos em que trabalhava, mas aos modos como era mantido pelo senhor, o que juridicamente nega o seu estado de direito.

Aulete, ao contrário de Moraes, categoriza "escravo" como substantivo, e o define utilizando-se de um dêitico para referi-lo como "Aquele que”, cuja forma pode ser substituída por “algo" ou “alguém”. A expressão "Aquele que" pressupõe a existência de alguém que vive "sob o poder do senhor", acionando a imagem do escravo.

Cabe destacar que, em Aulete, a vinculação do "escravo" é exclusiva com o senhor que o mantém como propriedade, embora o Estado tivesse o poder de intervir na concessão de alforria, em casos excepcionais, como alistamento militar e/ou combater o inimigo do Império nas guerras, entre outros casos.

Em Aurélio, na etimologia de "escravo", há um acréscimo do grego bizantino à origem dada por Aulete, significando que a existência dos escravos remonta à antiguidade grega. Nesse dicionário, a primeira acepção, na categoria de adjetivo, que determina a condição servil do "escravo", e a segunda, que define o "escravo", na categoria de substantivo, se assemelham quanto à reescrituração, mas significam diferentemente. A primeira mostra o estado de sujeição do escravo a um senhor que o mantém cativo; e a segunda acepção, que funciona como enunciado definidor, designa o “escravo" pela relação que estabelece com o seu senhor. A segunda acepção reescritura a primeira por substituição, e as duas retomam a acepção dada por Aulete: "Aquele que está sob o poder de um senhor, como sua propriedade privada."

Para Guimarães (2007, p. 87), o processo de reescrituração

... constrói o sentido das palavras e das expressões linguísticas, em virtude do próprio processo com que se dá. Nosso interesse, então, não está no fato de que uma retomada se faz sobre algo que é o mesmo, mas o contrário, ao se fazer, faz significar algo que não estava significado. 
Em Houaiss, o verbete "escravo" aparece ao mesmo tempo categorizado como adjetivo e substantivo, recobrindo uma única acepção que diz sobre o escravo e a sua condição. Essa acepção reescritura por expansão as acepções já vistas em Aulete e Aurélio, ao acrescentar as expressões "privado da liberdade" e "submetido à vontade absoluta", que predicam o estado do escravo, identificando-o duplamente na sociedade escravocrata brasileira. Com relação à etimologia, o dicionarista historiciza a origem do escravo, rememorando o que diz Aulete e Aurélio, e introduz o povo eslavo pela relação escravocrata a que era submetido pelos germanos e os bizantinos durante a Idade Média.

Nos dicionários lusitanos e brasileiros, o enunciado definidor designa a palavra entrada "escravo", não pelo significado denotativo ou etimológico de que é constituída, mas pela relação de sentido que estabelece com outras palavras nas enunciações em que é dita. Como o processo de designação se movimenta com o funcionamento da língua e dos sujeitos aí instituídos, as designações atribuídas ao "escravo", vão constituindo novos significados, pois, designar "é constituir significação como uma apreensão do real, que significa na linguagem na medida em que o dizer identifica este real para os sujeitos” (GUIMARÃES, 2002, p. 91).

\section{Liberdade}

\begin{tabular}{|l|l|}
\hline Moraes (1789) & Aulete (on-line) \\
\hline Liberdade, s. f. a faculdade, & (li.ber.da.de) Estado ou condição de \\
que a alma tem de fazer, ou & quem é livre. [...] Condição de quem \\
deixar de fazer alguma coisa, & não está submetido a nenhum \\
como mais quer. [...] \ Alforria, & constrangimento físico ou moral: Ela \\
que consegue, ou dá ao cativo. & $\begin{array}{l}\text { tinha ampla liberdade de ir e vir. } \\
\text { sf. [F.: Do lat. libertas,atis.] }\end{array}$ \\
\hline
\end{tabular}




\begin{tabular}{|l|l|}
\hline Aurélio (1975) & Houaiss (2001) \\
\hline Liberdade. [Do lat. libertate.] S.f. & liberdade $S . f .1$ grau de \\
1. Faculdade de cada um se & independência legítimo que um \\
decidir ou agir segundo a própria & cidadão, um povo ou uma nação \\
determinação: Sua liberdade, & elege como valor supremo, como \\
ninguém a tolhia. [...] 5. Estado ou & ideal (a justiça em termos absolutos é \\
condição de homem livre: dar & contrária à l.) [...] 4 condição daquele \\
liberdade a um prisioneiro, a um & que não é cativo ou que não é \\
escravo. & propriedade de outrem (pôr em l. um \\
& prisioneiro) (dar l. a um escravo). \\
& ETIM. lat. libertas, atis 'liberdade, \\
& condição de pessoa livre'; ver \\
& livr -; f. hist. sXV lyberdade; \\
& registram-se as f. ant. livridom e \\
& livridõoe sXV. \\
\hline
\end{tabular}

$\mathrm{Na}$ discursividade da escravidão brasileira, a palavra "liberdade" funcionou como o porvir de uma nova condição jurídica que garantisse ao escravo o estado de direito, senão igual ao do homem livre, mas livre da sujeição do homem livre. Assim, era comum nas discursividades vincular a liberdade do escravo ao mecanismo da alforria por oferta de valor.

No dicionário Moraes, a segunda acepção de "liberdade" define alforria que aparece determinada pela relativa "que consegue, ou dá ao cativo", retomando o já dito antes, em outro lugar, o que se diz no texto do verbete, com relação às modalidades de liberdade: por exemplo, em "que consegue", trata-se da alforria onerosa que se dá através da compra; e em "que dá ao cativo", a alforria é dada gratuitamente por decisão do próprio proprietário, em virtude dos bons serviços prestados pelo escravo, entre outras qualidades apreciadas pelo senhor.

Aulete, ao contrário de Moraes, define "liberdade" como "Estado ou condição de quem é livre", numa época em que as Constituições de Portugal e do Brasil já garantiam ao homem livre os direitos civis, dentre eles, o direito de "ir e vir", que o dicionarista retoma como efeito de pré-construído. Desse modo, os sentidos do verbete apontam para a condição jurídica do homem livre, do cidadão, e apaga-se a figura do liberto, a nova condição jurídica do escravo após a obtenção de sua liberdade. Aqui 
a integração do verbete com outros textos "se faz por uma relação transversal entre elementos diversos e a unidade à qual se reportam" (GUIMARÃES, 2010 , p. 22). Ou seja, os sentidos de "liberdade" vêm de outros textos com os quais o verbete se relaciona.

Aurélio apresenta duas acepções de "liberdade". Na primeira, temos um enunciado definidor que mostra como a sociedade diz sobre a "liberdade"; e na segunda, mostra a condição do homem livre que, a partir do exemplo, rememora a passagem do escravo a uma nova condição jurídica. Nesse texto, a segunda acepção em Aurélio reescritura, por substituição, a significação dada por Aulete: "Estado ou condição de quem é livre". Nesse movimento semântico, o que as diferencia é que, em Aurélio, a "liberdade" evoca a passagem do escravo à condição de liberto, enquanto Aulete não faz referência à escravidão.

Para André Collinot (apud MAZIÈRE, 1989, p. 48), o enunciado definidor é

... concebido como o lugar em que se constrói e se pode mostrar o "como se diz" de uma sociedade, ou seja, esse "pronto para dizer" [prêt à parler], muitas vezes, não advém do sentido dicionarizado, mas das definições predicativas ou dos enunciados definidores que são produzidos na relação do sujeito com o interdiscurso.

A primeira definição de "liberdade" em Houaiss aparece escalonada, graduada, como se a liberdade fosse processual e dependesse da escolha de cada indivíduo, povo e nação. Na segunda acepção, Houaiss reescreve as acepções dadas por Aulete e Aurélio por expansão, com o acréscimo das predicações "não é cativo ou que não é propriedade de outrem", numa relação de antonímia com o estado de escravidão.

Essas predicações, que poderiam atribuir propriedades à liberdade dos escravos, na teoria à qual nos filiamos, a Semântica do Acontecimento, se constituem, segundo Guimarães (2007, p. 80), "no acontecimento enunciativo", ou seja, "as palavras têm sua história de enunciação" (p. 81) e significam no acontecimento do dizer afetadas pelo já dito. 


\section{Poupança}

\begin{tabular}{|l|l|}
\hline Moraes (1789) & Aulete (on-line) \\
\hline Poupança (Não consta nesse & (pou.pan.ça) sf. \\
dicionário). & 1 Ação de poupar dinheiro. [...] \\
& 4 Econ. Parte da renda individual \\
& ou nacional que não é gasta em \\
& consumo. 5 Bras. Caderneta de \\
& poupança: Foi ao banco e abriu uma \\
& poupanca. \\
& {$[$ F.: poup(ar) + -ança. Hom./Par.: } \\
poupança (sf.), popança (sf.).]
\end{tabular}

\begin{tabular}{|l|l|}
\hline Aurélio (1975) & Houaiss (2001) \\
\hline Poupança. [De poupar + -ança.]. S. & 1 poupança (1821-1875 cf. \\
f. Economia, parcimônia: "Elvira & ACasTQ) ato de deixar de \\
era a própria cozinheira, um & consumir ou de gastar (um bem). \\
pouco por economia, um nem & {$[\ldots]$ ETIM poupar+anca; } \\
sempre bem disfarçado instinto de & 1821.1875 é a data para a acp. \\
poupança" (Ledo, Ivo. O Flautim, p. & 'sovenice', e 1899, para a acp. 'ato \\
53). Fam. Sovonice, mesquinhez, & de deixar de gastar (um bem)'. \\
avareza. & 2 poupança $s$. ECON red. de \\
& CADERNETA DE \\
& POUPANCA. SIN/VAR ver \\
& sinonímia de pecúlio. PAR ver \\
& poupança. \\
\hline
\end{tabular}

Chegamos ao verbete "poupança", que metaforiza um aparelho formal de liberdade (BENVENISTE, 1989), que inclui um conjunto de formas representadas por regras bancárias que fixam as condições para abertura da caderneta de poupança, dos depósitos e da restituição do pecúlio para a compra da liberdade.

Em Moraes, não aparece o registro do verbete "poupança", ou seja, esse vocábulo não fazia parte do léxico da língua portuguesa de Portugal à época da sua publicação, pois os primeiros bancos destinados exclusivamente ao pequeno poupador, em oposição aos bancos comerciais, foram criados, conforme Grinberg (2011), no final do século XVIII, na Europa, nas cidades 
de Brunswick, Hamburgo e Gênova, e se tornaram populares na Grã-Bretanha, a partir do início do século XIX. Assim, as relações entre banco e poupadores fundam um novo dizer na discursividade econômico-social de algumas cidades europeias, mas não no território português, onde essas novas práticas não haviam sido ainda instaladas na discursividade da sociedade portuguesa.

Em Aulete, as três acepções para "poupança" se assemelham quanto à atividade do ato de poupar, mantendo uma certa regularidade nos sentidos. A segunda acepção, de ordem econômica, define "poupança", expandindo os sentidos ao estabelecer um paralelo entre a renda individual e a renda do Estado que não é gasta. Já a última acepção, "Caderneta de Poupança", oriunda de brasileirismo, rememora o conjunto do enunciável das relações entre banco estatal ou privado e o poupador. No exemplo dado a esse enunciado, "Foi ao banco e abriu uma poupança", há um sujeito oculto, cujo espaço pode ser preenchido por qualquer sujeito poupador que estabeleça uma relação econômico-social com o banco, exceto o escravo, a quem o dicionário não faz referência; e por outro lado, temos um exemplo de enumeração por coordenação e contato, que mostra duas ações do sujeito poupador: 1 - "foi ao banco"; b) “abriu uma poupança”. Guimarães (2009, p. 49) define enumeração como "um modo enunciativo de atribuir sentidos a expressões linguísticas"; enquanto que para Lausberg (1966 apud GUIMARÃES, 2009, p. 49), a enumeração é “ uma acumulação coordenante em contato", ou seja, não se dá por reescrituração, mas por acúmulo de palavras e contatos distintos.

A acepção "Caderneta de Poupança" traz os sentidos instalados nas discursividades de homens livres e não livres da cidade do Rio de Janeiro, a capital onde se criou a primeira agência da Caixa Econômica, em 1861, para "receber as pequenas economias das classes menos abastadas" (SOUZA, 1914 apud GRINBERG, 2011, p. 140). Essa acepção mostra que o dicionarista lusitano está atento a não só o que diz a sociedade portuguesa, mas ao desenvolvimento econômico da ex-colônia. Aqui "poupança" designa "Caderneta de Poupança", que funciona como o instrumento que dá a forma material e histórica do registro da movimentação dos depósitos e dos rendimentos, com vistas à compra da liberdade.

Embora o dicionário Aurélio tenha sido publicado numa época em que os bancos estatais e privados já tinham atingido uma escala nacional, e oferecessem o serviço de poupança, não aparece nenhuma referência de 
"poupança" ligada à instituição bancária, e o exemplo dado, extraído da obra O Flautim, de Ivo Ledo, relaciona "poupança” à economia doméstica protagonizada por uma personagem de nome Elvira. Já Houaiss traz, inicialmente, uma acepção literária de "poupança" dada pelo português Antonio Feliciano Castilho, na tradução da obra D. Quixote, s.XIX, de Cervantes, como "ato de deixar de consumir ou de gastar (um bem)", em que a significação de "um bem", pela indeterminação que o constitui, pode não significar necessariamente recursos financeiros, mas outros bens como propriedades ou objetos de valor. Em seguida, traz, no enunciado econômico, a designação Caderneta de Poupança, rememorando as relações de poupança oferecidas pelas instituições bancárias.

\section{Considerações Finais}

Nas análises das relações de sentidos entre as palavras "poupança", "liberdade", "alforria" e "escravo" em duas épocas, observamos que, na segunda metade do século XIX, à época que a propaganda da Caixa nos transporta, o escravo de ganho, na relação econômico-social com o banco, é tomado pela temporalidade no acontecimento da compra de sua liberdade por meio da formação de um pecúlio. E é esse acontecimento que constitui a temporalidade, a partir da conjunção dos tempos passado, presente e futuro. $\mathrm{Na}$ perspectiva da temporalidade adotada por Guimarães (2002, 2011), vamos analisar como os sentidos se constituem no acontecimento da compra da liberdade, pelo escravo, intermediada pela Caixa, na segunda metade do século XIX.

A partir da inscrição do escravo na enunciação da Caixa, na condição de locutor-poupador, que comprou a sua liberdade, dizer "Comprei a liberdade com o dinheiro da poupança", só é possível porque recorta um passado como memorável no momento dessa enunciação, projetando a futuridade e/ou novas possibilidades de novas enunciações. E é só desse modo que o que se diz significa e constitui uma nova temporalização. $\mathrm{Ou}$ seja, parte do que foi dito (passado de rememorações) perpassa o que se diz (o presente da enunciação) e projeta (futuro) novas possibilidades de o escravo, investido na nova condição jurídica, dizer: "estou livre da escravidão", "sou liberto", "sou cidadão brasileiro.

Reportando-nos ao início do século XXI, época em que a propaganda é criada, rememoram-se 150 anos de história do povo português, africano 
e brasileiro, que são descritos por lexicógrafos luso-brasileiros, acarretando sentidos de continuidade, acréscimo, transformação e deslizamento nos verbetes "poupança”, "liberdade", "alforria" e "escravo", que historicizam duas épocas que se fundem e se rompem com a instituição do estado de direito do cidadão brasileiro.

$\mathrm{Na}$ propaganda da Caixa 150 Anos, o escravo não ocupa o lugar social de locutor que diz. Quem enuncia é a própria Caixa que, ao retomar a posição de locutor-intermediador de liberdade do escravo de ganho, rememora uma parte da história do Brasil, na qual, se antecipando à Lei do Ventre Livre (1871), permite ao escravo a formação de um pecúlio, que passa a assumir o lugar social de poupador na enunciação da Caixa, na segunda metade do século XIX.

No dizer da Caixa: "Os escravos pouparam na Caixa para comprar um bem que jamais deveria ter preço: a liberdade", ela diz dela mesma, dos escravos, dos libertos e dos livres, e rememora um passado que, tomado no presente da enunciação, projeta, neste século, outros sentidos, outras possibilidades para a geração oriunda dos libertos dizer: "nasci livre", "sou cidadão brasileiro", "posso investir em qualquer carreira". A Caixa, além de destacar a categoria do escravo escolhida para se inscrever na enunciação da poupança do banco, na posição de locutor-poupador, define a categoria "escravo de ganho", e descreve como se dá o agenciamento do escravo "até obter o suficiente para comprar sua carta de alforria".

Os sentidos das imagens produzidas na propaganda legitimam a história que a Caixa descreve, de modo que, no passado, a formação de um pecúlio no banco estatal era fundamental para o escravo adquirir a liberdade, e a linguagem como mediadora necessária entre o escravo de ganho e a Caixa, mantinha certa regularidade pelo funcionamento enunciativo das formas "poupança", "carta de alforria" e "liberdade", em que, na falta de uma delas na discursividade econômico-social, os sentidos de liberdade do escravo deslizam, não se materializam.

No enunciado "Os escravos pouparam na Caixa para comprar um bem [...]”, que funciona como título ou manchete no texto da propaganda, a expressão "Os escravos" universaliza os sujeitos que pouparam na Caixa, independentemente de outras categorizações que lhes foram atribuídas pelas atividades que exerciam na cidade e no eito. Aqui é importante destacar que a universalidade e a especificação do escravo tensionam os sentidos entre a categoria dos escravos de ganho que podiam poupar na Caixa e a dos 
escravos excluídos dessa prerrogativa. Aparentemente, a Caixa busca destacar apenas os escravos de ganho, mas, desfeita a transparência da linguagem, inclui os demais escravos, como efeito da posição desses escravos na enunciação da Caixa, que ocupam o mesmo lugar que os escravos de ganhos. Desse modo, é possível obter as seguintes leituras:

1. Todos os escravos, sem exceção, pouparam na Caixa Econômica;

2. Somente escravos de ganho cedidos pelo senhor poupavam na Caixa Econômica.

Nos enunciados "um bem que jamais deveria ter preço" e "Pagavam assim por um direito que jamais lhes deveria ter sido roubado", as formas "um bem" e "um direito" remetem à liberdade, ou melhor, reescrevem por substituição "liberdade", numa relação sinonímica; e o emprego dos dêiticos temporais "jamais" e "nunca" colocam a Caixa na posição de juiz que julga a nação brasileira pela negação de liberdade aos escravos, pelo efeito de seu lugar de instituição financeira que intermediava a liberdade do escravo na segunda metade do século XIX.

Retomando a nossa proposta, diria que as palavras "escravo", "poupança", "alforria" e "liberdade", enquanto unidades textuais, são integradas por enunciados cujos sentidos vêm de outros textos com os quais elas se relacionam, produzindo sentidos de liberdade para o escravo. Neste século, elas rememoram, na comemoração dos 150 anos da Caixa, parte de uma história e da memória do povo reatualizada pelo dicionário que, além de ser o instrumento que busca unificar, regularizar e institucionalizar o saber lexicográfico do país, significa também pelas possibilidades de interpretação e de trazer para cada época os modos de dizer de uma determinada sociedade em convívio com os modos de dizer de outras sociedades.

\section{Referências}

BENVENISTE, E. O aparelho formal da enunciação. In:

BENVENISTE, E. Problemas de Linguística Geral II. Tradução Eduardo

Guimarães. Campinas: Pontes, 1989. p. 81-90.

DUBOIS, J. et al. Dicionário de Linguística. São Paulo: Cultrix, 1997. 
FERREIRA, A. B. H. Novo Dicionário da Lingua Portuguesa. Rio de Janeiro: Nova Fronteira, 1975.

GRINBERG, K. A poupança: alternativas para a compra da alforria no Brasil (2a metade do século XIX). Revista das Indias, v. 71, n. 251, p. 137158, 2011. Disponível em:

$<$ http://revistadeíndias.revistas.csic.es/index.php/revistadeindias/article/ viewFile>. Acesso em: 17 jul. 2011.

GUIMARÃES, E. Sinopse dos estudos do português no Brasil: a gramatização brasileira. In: GUIMARÃES, E.; ORLANDI, E. (Orgs.). Lingua e cidadania: o português no Brasil. Campinas: Pontes, 1996.

GUIMARÃES, E. A Semântica do Acontecimento: um estudo enunciativo da designação. Campinas: Pontes, 2002.

GUIMARÃES, E. Domínio semântico de determinação. In:

GUIMARÃES, E.; MOLLICA, M. C. (Orgs.). A palavra: forma e sentido. Campinas: RG Editores, 2007.

GUIMARÃES, E. et al. Os falantes e as línguas: multilinguismo e ensino. São Paulo: Cefiel/IEL/UNICAMP, 2008.

GUIMARÃES, E. A enumeração: funcionamento enunciativo e sentido. Cadernos de Estudos Linguísticos, Campinas, n. 1, maio 2009 [ago. 1978].

HORTA, J. N. Léxico e Língua Nacional: apontamentos sobre a história da lexicografia no Brasil. In: ORLANDI, E. (Org.). História das Idéias Linguísticas: construção do saber metalingüístico e constituição da língua nacional. Campinas: Pontes; Cáceres: UNEMAT, 2001.

HORTA, J. N. Dicionarização no Brasil: condições e processos. In: HORTA, J. N.; PETTER, M. (Orgs.). História do saber lexical e constituição de um léxico brasileiro. São Paulo: Humanitas; FFLCH-USP; Pontes, 2002.

HORTA, J. N. Dicionários no Brasil: análise e história. Campinas: Pontes; São Paulo: Fapesp; São José do Rio Preto: Paperp, 2006.

HOUAISS, A. Dicionário Honaiss da Lingua Portuguesa. Rio de Janeiro: Objetiva, 2001. 
IDICIONÁRIO AULETE. Dicionário on-line de português. Disponível em: <http://aulete.uol.com.br/

site.php?mdl=aulete_digital\&op=o_que_e $>$. Acessos em: out. 2011.

MAZIÈRE, F. O enunciado definidor: discurso e sintaxe. In:

GUIMARÃES, E. (Org.). História e sentido na linguagem. Campinas: Pontes, 1989. p. 47-59.

ORLANDI, E. Análise de discurso: princípios e procedimentos. Campinas: Pontes, 1996.

ORLANDI, E. Lexicografia discursiva. In: ORLANDI, E. Lingua e conhecimento linguístico: para uma história das idéias no Brasil. São Paulo: Cortez, 2002. p. 101-122.

SILVA, A. de M. Diccionario da Lingua Portugueza, composto pelo Padre Rafael Bluteau, reformado, e acrescentado por Antonio de Moraes. Lisboa: Officina de Simão Thaddeo Ferreira, 1789.

ZATTAR, N. Os sentidos de liberdade dos escravos na constituição do sujeito da enunciação sustentado pelo instrumento de alforria. 2000. Dissertação (Mestrado em Linguística) - Universidade Estadual de Campinas, Campinas.

Recebido em abril de 2013 Aprovado em agosto de 2013 